\title{
Citric Acid Production by Aspergillus Niger on a Corn Cob Solid Substrate using One-factor-at-a-time Optimisation Method
}

\author{
M.G. Addo ${ }^{1}$, A. Kusi ${ }^{2}$, L.A. Andoh ${ }^{3}$ and K. Obiri-Danso ${ }^{4}$ \\ Dept. of Theoretical and Applied Biology, Kwame Nkrumah University of Science \& Technology, Kumasi, Ghana 1,2,3,4
}

\begin{abstract}
The potential of corn cobs as solid substrates for the production of citric acid was investigated using Aspergillus niger KA88, a local isolate as the fermenting organism. One-factor-at-a-time (OFAT) model was used to optimize the fermentation media to achieve the maximum yield of citric acid. The fermentation parameters studied and their resultant optimised levels were found to be $28{ }^{\circ} \mathrm{C}$ incubation temperature, $15 \%$ (w/v) sucrose for 6 days fermentation period, $50 \%$ each of $(0.5-1 \mathrm{~mm}$ and $3-5 \mathrm{~mm})$ particle sizes. Di-ammonium hydrogen phosphate was the preferred nitrogen source at a concentration of $4 \mathrm{~g} / \mathrm{l}$. The final OFAT fermentation media gave $138.24 \mathrm{~g}$ anhydrous citric acid/kg dry corn cob. In general, corn cob proved to be a highly promising solid substrate for commercial citric acid production.
\end{abstract}

Keywords: Substrate, Aspergillus niger, fermentation, Temperature, One-factor-at-a-tme model.

\section{INTRODUCTION}

Citric acid is widely used to impart a pleasant, tart flavour currency. The average maize farmer earns GHC 296 per to foods and beverages. It also finds applications as a hectare as gross margin per season, with a meager GHC function of additive detergents, pharmaceuticals, 0.88 as return on investment [7]. For not dumping or cosmetics and toiletries. It is therefore an important burning the corn cobs, but gathering and sending them to commodity in our everyday life with worldwide tonnage "Cobs Point of Sale" the farmer is able to earn extra of 1.8 million in 2010 [1]. Aspergillus niger, a ubiquitous income by transforming waste to wealth. In this regard, fungus, alone is credited with the production of over 1 'Cob Processing Units' could be established around major million tonnes of citric acid annually. Among the maize farming communities, where some microbial microorganisms, the fungus $A$. niger has remained the isolates from the naturally degrading cobs could be tested organism best suited for commercial production, because, as starter cultures for the production of compounds of it produces more citric acid per unit time [2]. Although economic importance such as organic acids, sugars, citric acid can be produced chemically from the juice of bioethanol and nutritious animal feed supplements. This citrus fruits, fungal fermentation to produce citric acid has study therefore seeks to maximize citric acid production gained more prominence than chemical synthesis because by Aspergillus niger using corn cob as the solid substrate the latter is a much more expensive endeavour [3]. Again, by optimizing the fermentation media.

even though submerged fermentation is known to dominate worldwide citric acid production, recent works on solid state fermentation by [2-4] yielded considerable amount of citric acid. Over $60 \%$ of Ghanaians engage in agriculture in one way or the other, producing millions of tonnes of agro-wastes such as corn cobs.

These pose serious health and aesthetic environmental problems and efforts aimed at disposing these corn cobs have proven to be a mirage. Corn is an important cereal in Ghana and other parts of West and Central Africa. Citric acid production in Sub-Sahara Africa and for that matter Ghana has been on the quiet for one reason or the other despite increasing disposal problems and efforts at byproduct utilisation. In Ghana, corn cobs are used as a fuel in direct combustion in cooking in maize growing areas, while in the United States, technology is well advanced in using cobs for cellulosic ethanol, co-firing and gasification projects [5-6]. Local industries have to spend the meagre profits earned to mob up the little foreign exchange in the system to import citric acid and other organic acids, which puts more pressure on an already struggling Ghanaian

\section{MATERIALS AND METHODS}

A. Pre-treatment of corn cobs

The corn cobs were collected from local farmers after threshing in Antoa, Kwabre East District, Ashanti-Ghana, and brought to the lab for various pretreatments to be carried on them.

\section{B. Isolation of Aspergillus niger KA88}

This particular Aspergillus niger strain was isolated from a rotten cassava by serial dilution in the Microbiology Research Laboratory of the Kwame Nkrumah University of Science and Technology. One millimeter of each diluent was plated on the solidified agar plates by streaking. The plates were incubated at $37{ }^{\circ} \mathrm{C}$ for 3-5 days to ensure maximum fungal growth. The fungal strains were purified by re-streaking on the medium and each pure culture were maintained on Potato Dextrose Agar (PDA) slants and stored at $4{ }^{\circ} \mathrm{C}$ in a refrigerator. The isolate was therefore named as Aspergillus niger KA88. Sub-culturing was done monthly on slopes of potato dextrose agar at $30^{\circ} \mathrm{C}$ for 7 days. 
C. Solid state production of citric acid

To $10 \mathrm{~g}$ of substrate in each Erlenmeyer flask $(250 \mathrm{ml}), 35$ $\mathrm{ml}$ stock mineral salt solution with a concentration of $(\mathrm{g} / \mathrm{l})$ : ( $\mathrm{NH} 4)_{2} \mathrm{SO}_{4}, 5 ; \mathrm{KH}_{2} \mathrm{PO}_{4}, 5 ; \mathrm{MgSO}_{4} .7 \mathrm{H}_{2} \mathrm{O}, 0.25 ; \mathrm{NaCl}$, 0.25 ; and $15 \%(\mathrm{~g} / \mathrm{l})$ sucrose was added. The resultant corn cob in each flask gave the following salt concentration in terms of $\mathrm{kg}$ dry corn cob: $17.5 \mathrm{~g}\left(\mathrm{NH}_{4}\right)_{2} \mathrm{SO}_{4}, 17.5 \mathrm{~g}$ $\mathrm{KH}_{2} \mathrm{PO}_{4}, 0.88 \mathrm{~g} \mathrm{NaCl}, 0.88 \mathrm{~g} \mathrm{MgSO}_{4} \cdot 7 \mathrm{H}_{2} \mathrm{O}$ and $525 \mathrm{~g}$ of sucrose. $0.1 \mathrm{M} \mathrm{NaOH} / \mathrm{HCl}$ was used to adjust the $\mathrm{pH}$ of the medium to 5 . The flask was cotton plugged and wrapped by two layers of aluminium foil and then sterilised at $121^{\circ} \mathrm{C}$ for 15 minutes.

After sterilisation by double autoclaving, the flasks were cooled and inoculated with $2 \mathrm{ml}$ homogenised inoculum culture of $1.0 \times 10^{7}$ spores $/ \mathrm{ml}$ under aseptic conditions and incubated at $30{ }^{\circ} \mathrm{C}$ for 6 days. Each fermentation parameter was investigated and the outcome introduced into the succeeding parameter - in a one-factor-at-a-time manner - as a means of gradually optimizing the fermentation media. At the end of the fermentation, 9 parts of distilled water was added to 1 part of the fermented substrate in the flask and vortexed for 10 mins to extract the impregnated citric acid to the mycelia. The broth was filtered with mash followed by Whatman no. 1 filter paper and the supernatant was analysed for citric acid content, a modification of [8].

D. Analytical Technique

Citric acid was determined titrimetrically (AOAC) [9] by using $0.1 \mathrm{NaOH}$ and phenolphthalein as indicator.

\section{RESULTS AND DISCUSSION}

A. Effect of Incubation Temperature on Citric Acid Production

At $26{ }^{\circ} \mathrm{C}$, low amount of citric acid was produced (Table I), which may be attributed to low enzyme activity of the fermenting organism. As temperature increases, rate of reaction also increased, until it reached its optimal threshold of $28^{\circ} \mathrm{C}$.

At temperatures above $28{ }^{\circ} \mathrm{C}$, deactivation effect of temperature on endogenous metabolism set in, leading to a reduction in the biosynthesis of citric acid. Selahzadeh and Roehr [10] asserted that, at lower temperatures, analysing the metabolic effects of the fermenting organism show a waste of large amounts of the carbon source, primarily due to an increase in the organism's respiratory activity. Roukas [11] also reports that, at higher temperatures, there is the inhibition of the enzyme citrate synthase; the terminal enzyme of the pathway responsible for the biosynthesis of citric acid. This rather aids in the accumulation of oxalic acid at such temperatures.

Furthermore, higher fermentation temperatures result in severe moisture losses, making the environment unfavourable for growth. Kareem and Rahman, [12] in their work on the production of citric acid using pineapple waste under solid state fermentation had the highest citric acid titre $(43.5 \mathrm{~g} / \mathrm{kg})$ at $30{ }^{\circ} \mathrm{C}$. The $28{ }^{\circ} \mathrm{C}$ optimum temperature falls within the range observed by Szewcyzk and Myszka [13] on the growth of Aspergillus niger to be between $26^{\circ} \mathrm{C}-34{ }^{\circ} \mathrm{C}$.
TABLE I: Mean amount of citric acid produced at different temperature of incubation

\begin{tabular}{|c|c|c|}
\hline $\begin{array}{c}\text { Incubation } \\
\text { Temp't }\left({ }^{\circ} \mathbf{C}\right)\end{array}$ & $\begin{array}{c}\text { Citric Acid } \\
\text { Produced } \\
(\mathbf{g} / \mathbf{k g} \text { DCC) }\end{array}$ & $\begin{array}{c}\text { Standard } \\
\text { Deviation }\end{array}$ \\
\hline 26 & 32.64 & 1.985 \\
\hline 28 & 46.72 & 2.161 \\
\hline 30 & 34.00 & 2.014 \\
\hline 32 & 16.00 & 1.880 \\
\hline 34 & 12.80 & 1.564 \\
\hline
\end{tabular}

(Substrate to moisture ratio: $80 \%$, Incubation temperature: $30^{\circ} \mathrm{C}, \mathrm{pH}$ : 5, Sugar source: $15 \%$ g/l sucrose, Fermentation period: 6 days, Particle size: 3-5mm, Initial inoculum size: $2 \mathrm{ml}$ of $1 \times 10^{7}$ spores $/ \mathrm{ml}$, Nitrogen source: $5 \mathrm{~g} / \mathrm{l}$ Ammonium sulphate)

B. Effect of Sugar Concentration at Different Fermentation Periods on Citric Acid Production

The low amount of citric acid produced (Table II) may be due to unavailability of readily metabolised carbon source in the control media. Sucrose and glucose are readily metabolised by Aspergillus niger, so it is added to the corn cob substrate for easy uptake, for the growth of the fungus. Karimi [14] reports that the fungi cultures after utilizing the readily metabolized sugar source are primed to hydrolyse the lignocellulosic components of corn cobs. The general rise in citric acid titres from day two and peaking on day six, and the ensuing fall on day seven may be due to the age of fungus, depletion of the readily metabolised carbon source or nitrogen. This exhaustion of fermentable sugars may activate a decay in the enzyme system. The organism then tends to feed on the citric acid, secreted into the fermentation media, or citric acid catalysis may have ensued due to the accumulation of waste products in the media. Largely, increasing the sugar concentration resulted in a considerable increase in the amounts of citric acid produced. Peksel and Kubicek [15], hold the view that, a high rate of acidogenesis in A. niger is observed only under conditions of high glycolytic metabolism and can be induced by the addition of an excess amount of sucrose or other carbohydrates. Tkacz and Lange, [16] report that, production of more citric acid by the sucrose induced culture to glucose may be attributed to the production of an extracellular mycelium bound invertase by $A$. niger that is active at low $\mathrm{pH}$ and rapidly hydrolyses sucrose but the presence of glucose represses the genes that encode invertase. Moreover, the two glucose transporters found in A. niger are strongly susceptible to citrate inhibition, thereby terminating citric acid accumulation at some point, even though much of the glucose substrate still exist in the medium. The $20 \%$ sucrose media showed a steady rise in citric acid titres and did not witness any drop on the day seven as evident in the other media. Roukas [11] reports that further increase of sugar concentration above $20 \%(\mathrm{w} / \mathrm{v})$ results in a decrease in the rate of citric acid accumulation as a result of reduced water activity and plasmolysis. This reduced water activity and plasmolysis extend the lag phase of the fungus, reducing fungal numbers, and thereby the amount of citric acid secreted outside the hyphal walls. Ishaq et al. 
[17] in their work reports that citric acid production starts sucrose is the best sugar source for citric acid production. after a lag phase of one day and peaks at the onset of They further backed their conclusions by showing the stationary phase or even late. This observation is in line direct relationship that aconitase has on the sugar source with the works of (Hossain et al.; Papagianni) [18-19] that during citric acid accumulation.

TABLE II: Effect of Sugar Concentration at Different Fermentation Periods on Citric Acid Production

\begin{tabular}{|c|c|c|c|c|c|c|}
\hline \multirow{2}{*}{$\begin{array}{l}\text { Fermentation } \\
\text { media }\end{array}$} & \multicolumn{6}{|c|}{ Mean Citric acid (g/kg DCC) at different fermentation periods (days)/SD } \\
\hline & 2 & 3 & 4 & 5 & 6 & 7 \\
\hline $\begin{array}{l}\text { Corn cob only } \\
\text { (control) }\end{array}$ & 13.68/2.352 & 14.73/2.332 & 16.44/2.340 & 17.15/2.411 & 18.78/2.377 & $16.38 / 2.329$ \\
\hline $\begin{array}{l}\text { Corn cob }+5 \% \\
\text { glucose }\end{array}$ & 18.84/2.300 & 19.78/2.423 & 20.24/2.398 & 21.96/2.435 & 22.03/2.443 & 21.34/2.322 \\
\hline $\begin{array}{l}\text { Corn cob }+10 \% \\
\text { glucose }\end{array}$ & 21.67/2.401 & 23.96/2.421 & 26.01/2.427 & $\mathbf{2 7 . 8 8} / 2.403$ & 29.31/2.433 & 26.75/2.392 \\
\hline $\begin{array}{l}\text { Corn cob }+15 \% \\
\text { glucose }\end{array}$ & 24.50/2.413 & $\mathbf{2 6 . 4 4 / 2 . 4 1 9}$ & 30.98/2.456 & 32.17/2.438 & 33.00/2.429 & $\mathbf{3 1 . 3 3} / 2.410$ \\
\hline $\begin{array}{l}\text { Corn cob }+20 \% \\
\text { glucose }\end{array}$ & 22.32/2.406 & $\mathbf{2 4 . 5 4} / 2.422$ & 26.71/2.430 & $\mathbf{2 8 . 5 6} / 2.428$ & 29.66/2.387 & 30.23/2.392 \\
\hline $\begin{array}{l}\text { Corn cob + 5\% } \\
\text { sucrose }\end{array}$ & $\mathbf{2 1 . 4 5 / 2 . 4 0 8}$ & 22.91/2.405 & 24.12/2.414 & $25.66 / 2.426$ & 27.08/2.425 & 25.35/2.404 \\
\hline $\begin{array}{l}\text { Corn cob }+10 \% \\
\text { sucrose }\end{array}$ & 25.56/2.427 & $\mathbf{2 7 . 8 8} / 2.439$ & 30.26/2.420 & $\mathbf{3 3 . 4 5} / 2.423$ & $\mathbf{3 5 . 1 4} / 2.436$ & 31.77/2.408 \\
\hline $\begin{array}{l}\text { Corn cob }+15 \% \\
\text { sucrose }\end{array}$ & 31.11/2.416 & $35.67 / 2.453$ & 40.58/2.466 & 45.27/2.472 & 48.60/2.512 & 42.04/2.500 \\
\hline $\begin{array}{l}\text { Corn cob } 20 \% \\
\text { sucrose }\end{array}$ & 28.50/2.422 & 32.82/2.430 & $\mathbf{3 5 . 6 3 / 2 . 4 4 4}$ & 39.25/2.461 & 41.94/2.468 & 42.68/2.490 \\
\hline
\end{tabular}

(Substrate to moisture ratio: $80 \%$, Incubation temperature: $28^{\circ} \mathrm{C}, \mathrm{pH}: 5$, Sugar source: $15 \%$ g/l sucrose, Fermentation period: 6 days, Particle size: 3-5mm, Initial inoculum size: $2 \mathrm{ml}$ of $1 \times 10^{7}$ spores $/ \mathrm{ml}$, Nitrogen source: $5 \mathrm{~g} / \mathrm{l}$ Ammonium sulphate): $S D=$ Standard deviation

C. Effect of Particle Size/Distribution on Citric Acid Production

The smaller the particle size, the larger the surface area of the corn cob particles. This increases the availability of substrate to the Aspergillus niger, hence citric acid production is favoured, as a consequence of a more pronounced contact catalysis. The results of this study contradicts this assertion, in that, the finest corn cob particles used in this study produced the lowest amount of citric acid (Table III).

As the particle size was increased to some extent, the citric acid titres also increased. Kumar and Jain, [20] in their findings concluded that the high packing densities evident in smaller sized particles restrict airflow and inhibit fungal growth. Further increases in the particle size beyond the $(3.0-5 \mathrm{~mm}=\mathrm{c})$, led to a decrease in the amount of citric acid produced. This is contrary to earlier assertion that relatively larger particle sizes increase the rate of heat and mass transfer in the media, to counteract the highly exothermic respiratory metabolism of A. niger, hence, resulting in increases in citric acid titres.

The reason may be, for the $10 \mathrm{~g}$ corn cob supplied in each fermenter, the media containing the larger particle sizes were not much exposed to the fermenting organism as there was a considerable reduction in the surface area. Therefore, an effective balance of increasing substrate availability to the fermenting fungus and ensuring adequate heat and mass transfer within the media has to be the utmost priority.
In this instance, localised build-up of temperature and nonhomogenous fermentation conditions are eradicated. This is evident in Table III, where the finest particle size which favours substrate availability was mixed with a relatively larger particle size in a 1:1 ratio and ended up as the media with the maximum citric acid produced. This compares favourably with the results from Gopinath [21] on the influence of particle size on citric acid production by Aspergillus niger using rice chaff and sesamum oil cake as substrates; and also Bari et al. [22] on the effect of particle size on the production of citric acid from oil palm empty fruit branches as new substrate by wild Aspergillus niger.

TABLE III: Amount of citric acid produced at different particle size and/or distribution

\begin{tabular}{|l|l|l|}
\hline $\begin{array}{l}\text { Particle size } \\
\text { and/or } \\
\text { distribution }\end{array}$ & $\begin{array}{l}\text { Citric Acid } \\
\text { Produced } \\
\text { (g/kg DCC) }\end{array}$ & $\begin{array}{l}\text { Standard } \\
\text { Deviation }\end{array}$ \\
\hline$(0.5-1 \mathrm{~mm}=\mathrm{a})$ & 17.92 & 2.316 \\
\hline$(1.0-3 \mathrm{~mm}=\mathrm{b})$ & 26.88 & 2.421 \\
\hline$(3.0-5 \mathrm{~mm}=\mathrm{c})$ & 37.12 & 2.465 \\
\hline$(5.0-7 \mathrm{~mm}=\mathrm{d})$ & 35.20 & 2.445 \\
\hline$(7.0-10 \mathrm{~mm}=\mathrm{e})$ & 29.44 & 2.399 \\
\hline $\mathrm{a}+\mathrm{b}(1: 1)$ & 42.88 & 2.560 \\
\hline $\mathrm{a}+\mathrm{c}(1: 1)$ & 51.84 & 2.608 \\
\hline $\mathrm{a}+\mathrm{d}(1: 1)$ & 48.08 & 2.597 \\
\hline $\mathrm{a}+\mathrm{e}(1: 1)$ & 41.60 & 2.553 \\
\hline
\end{tabular}

(Substrate to moisture ratio: $80 \%$, Incubation temperature: $28^{\circ} \mathrm{C}, \mathrm{pH}$ : 5, Sugar source: $15 \% \mathrm{~g} / \mathrm{l}$ sucrose, 
Fermentation period: 6 days, Particle size: varried, Initial inoculum size: $2 \mathrm{ml}$ of $1 \times 10^{7}$ spores $/ \mathrm{ml}$, Nitrogen source: $5 \mathrm{~g} / \mathrm{l}$ Ammonium sulphate)

D. Effect of Different Nitrogen Sources on Citric Acid Production

For the nitrogen compounds analysed, Di-ammonium hydrogen phosphate ; $\left(\mathrm{NH}_{4}\right)_{2} \mathrm{HPO}_{4}$, Di-ammonium hydrogen sulphate; $\left(\mathrm{NH}_{4}\right)_{2} \mathrm{SO}_{4}$, Urea ; $\mathrm{CO}\left(\mathrm{NH}_{2}\right)_{2}$ and Ammonium chloride; $\mathrm{NH}_{4} \mathrm{Cl}$ reflected the amount of citric acid produced in decreasing order (Table IV). This same order also reflected the ability to excrete stoichiometric amounts of protons into the media, thereby reducing the $\mathrm{pH}$. Brainard and Tsao [23] observed that, within $24 \mathrm{~h}$ after the inoculation of spores, ammonium ions are rapidly consumed with the excretion of stoichiometric amounts of protons.

As a result the vegetative growth of germinated spores slows down due to the decrease in $\mathrm{pH}$ and citric acid accumulation ensues. In contrast, the hydrolysis of urea liberates ammonia into the fermentation media, leading to a rapid alkalinisation of the media. Hence, biomass accumulation is favoured, to the detriment of citric acid accumulation. With regards to this assertion, a consciously chosen concentration of the nitrogen source, should take cognizance of the initial inocula levels of $A$. niger needed to utilise the ammonia present for the early onset of citric acid accumulation. In fact, literature shows that ammonium sulphate is the preferred source of nitrogen in microbial citric acid production [4, 19-24]. In this study, the di-ammonium hydrogen sulphate gave the optimum citric acid yield of $138.24 \mathrm{~g}$ citric acid $/ \mathrm{kg}$ dry corn cob, with the highest for ammonium sulphate being 115.20 $\mathrm{g} / \mathrm{kg}$ DCC. Nitrogen is a constituent of many vital compounds including amino acids, basic proteins, enzymes, coenzymes and nucleic acids. An optimum nitrogen concentration must be used to maintain proper $\mathrm{C}: \mathrm{N}$ ratio in the optimum range because citric acid synthesis will decrease at both lower and higher nitrogen levels [4].

TABLE IV: Effects of Different Nitrogen Sources and their Limitations on citric acid production

\begin{tabular}{|c|c|c|c|}
\hline $\begin{array}{l}\text { Nitrogen } \\
\text { Source }\end{array}$ & Conc.(g/l) & $\begin{array}{l}\text { Citric Acid } \\
\text { Produced }(g / k g)\end{array}$ & SD \\
\hline \multirow[t]{4}{*}[\mathrm{CO}(\mathrm{NH}_{2})_{2}]{} & 3 & 66.56 & 3.1 \\
\hline & 4 & 44.16 & 2.6 \\
\hline & 5 & 12.80 & 1.9 \\
\hline & 6 & 10.24 & 1.8 \\
\hline \multirow[t]{4}{*}[(\mathrm{NH}_{4})_{2}\mathrm{SO}_{4}]{} & 3 & 97.92 & 4.5 \\
\hline & 4 & 115.20 & 5.2 \\
\hline & 5 & 51.12 & 2.9 \\
\hline & 6 & 19.84 & 2.0 \\
\hline \multirow[t]{4}{*}[\mathrm{NH}_{4}\mathrm{Cl}]{} & 3 & 38.40 & 3.2 \\
\hline & 4 & 30.08 & 3.3 \\
\hline & 5 & 21.76 & 2.1 \\
\hline & 6 & 19.84 & 2.2 \\
\hline \multirow[t]{4}{*}[(\mathrm{NH}_{4})_{2}\mathrm{HPO}_{4}]{} & 3 & 120.96 & 5.6 \\
\hline & 4 & 138.24 & 5.9 \\
\hline & 5 & 112.00 & 5.1 \\
\hline & 6 & 51.20 & 2.8 \\
\hline
\end{tabular}

(Substrate to moisture ratio: $80 \%$, Incubation temperature: $28^{\circ} \mathrm{C}, \mathrm{pH}$ : 5, Sugar source: $15 \%$ g/l sucrose, Fermentation period: 6 days, Particle size: $5 \mathrm{~g}$ each of $(0.5-1 \mathrm{~mm}$ and 3-5mm), Initial inoculum size: $2 \mathrm{ml}$ of $1 x$ $10^{7}$ spores $/ \mathrm{ml}$ )

\section{CONCLUSION}

In conclusion, the results obtained in the study proved the effectiveness of the OFAT studies in maximizing citric acid production. The first parameter trial conducted on the effect of incubation temperature produced $46.72 \mathrm{~g}$ citric acid per $\mathrm{kg}$ dry corn cob. After three other parameters were investigated, with the outcome of each trial been incorporated into the succeeding one, $138.24 \mathrm{~g}$ citric acid per kg dry corn cob was produced.

As a result, $91.52 \mathrm{~g}$ citric acid per kg dry corn cob was the amount of citric acid realized from the OFAT studies, thus the difference between the first and last trial. The study thus presents corn cob as a potential solid substrate for the commercial production of citric acid in Ghana.

\section{ACKNOWLEGEMENT}

We are very thankful to the Technicians at the Microbiology Laboratory at the Department of Theoretical and Applied Biology, Kwame Nkrumah University of Science and Technology, Kumasi, Ghana for facilitating the Lab. Work.

\section{REFERENCES}

[1] IHS Chemical (2012) Citric acid. [Online] IHS Chemical. Available

http://www.ihs.com/products/chemical/planning/ceh/citricacid.aspx.[Accessed 30/09/2013].

[2] G. Narasimha, A. P. Kumar, A. Srilakshmi and K. H. Goud (2012). Citric acid production by Aspergillus niger through solid state fermentation using fruit wastes. Biotechnology An Indian Journal, 6(3), 93-96.

[3] Q. Iqbal (2008) Quantification of Fungal biomass growth during Citric Acid production by Aspergillus niger on extended clay solid substrate. (Published Master's thesis, Department of Bioresource Engineering, McGill University, Montréal).

[4] S. Javed, M. Asgher, M. A. Sheikh, H. Nawaz and A. Jamil, (2011) Enhanced citric acid production by Aspergillus niger EB-3 mutant using an inert solid support in molasses medium. African Journal of Biotechnology 10(55), 11784-11791.

[5] B. G. Del Campo (2010). Corncob dry matter loss in storage as affected by temperature and moisture content. Graduate Thesis and Dissertations. Paper 11796, Iowa State University.

[6] Extension (2014) Corn cobs for biofuel production [Online] Extension. Available athttp://www.extension.org/pages26619/corncobs-for-biofuel-production\#. VZvDR0YmyU4 [Assessed 07/01/2015]

[7] C. Ragasa, A. Chapoto and S. Kolavalli, (2014) Maize productivity in Ghana. Intl. Food Policy Res. Inst., 1-4.

[8] H. Feleke, (2010) Small-scale citric acid production on solid-state fermentation using Aspergillus niger. Published thesis (MSc.) Faculty of Science, Addis Ababa University.

[9] AOAC (1995). Official Methods of Analysis.16th edn. Association of Official Analytical Chemist, Washington D.C.

[10] R. M. Selahzadeh and M. Roehr (2003) Citric acid fermentation and the effects of temperature. Acta Biotechnol., 23(1), 95-100.

[11] T. Roukas (2014) Biotechnology of citric acid production. In Pometto, A., Shetty, K. Paliyath, G. and Levin, R. E (Eds), Food biotechnology, (2nd ed., pp. 350-395). USA: CRC Press.

[12] S. O. Kareem and R. A. Rahman (2011) Utilisation of banana peels for citric acid production by Aspergillus niger. Agric. Biol. J. N. Am., 4(4), 384-387. 
[13] K. W. Szewcyzk and I. Myszka, (1994) The effect of temperature on the growth of Aspergillus niger in solid state fermentation. Bioprocess. Eng., 10, 123-126.

[14] K. Karimi (2015) Lignocellulosic-based bioproducts. Cham: Springer, 16

[15] A. Peksel and C. P. Kubicek, (2003) Effects of sucrose concentration during Citric Acid Accumulation by Aspergillus niger. Turk J Chem, 27, 581-590.

[16] J. S. Tkacz and L. Lange (2004). Advances in fungal biotechnology for industry, agriculture, and medicine. New York: Kluwer Academic/Plenum Publishers, 312-319.

[17] A. A. Ishaq, I. H. Sikander and M. Qadeer, (2002). Time course profile of citric acid fermentation by Aspergillus niger and its kinetic relations. Journal of Biological Sciences, 2, 760-761.

[18] M. Hossain, J. D. Brooks and I. S. Maddox (1984) The effect of the sugar source on citric acid production by Aspergillus niger. Applied Microbiology and Biotechnology., 19(6), 393-397.

[19] M. Papagianni (2007) Advances in citric acid fermentation by Aspergillus niger: Biochemical aspects, membrane transport and modeling. Biotech. Adv. 25(3), 244-263.

[20] D. Kumar and V. K. Jain (2008) Solid state fermentation studies of citric acid production. African Journal of Biotechnology, 7 (5), 644-650.

[21] S. M. Gopinath (2013) Influence of particle size on citric acid production by Aspergillus niger using rice chaff and sesamum oil cake as substrates. International Journal of Innovative Research in Science Engineering and Technology, 2(12) 7905 7910.

[22] M. N. Bari, M. Z. Alam, S. A. Muyibi, P. Jamal and A. A. Mamun (2010) Effect of particle size on the production of citric acid from oil palm empty fruit branches as new substrate by wild Aspergillus niger. Journal of Applied Sciences. 10(21), 2648 -2652 .

[23] A. P. Brainard and G. T. Tsao, (1999) Recent Progress in Bioconversion of Lignocellulosics. In: Advances in biochemical engineering, biotechnology. Berlin: Springer, 65, 253-262.

[24] T. O. Femi-Ola and V. A. Atere (2013) Citric acid production from brewers spent grain by Aspergillus niger and Saccharomyces cerevisiae. International Journal of Research in BioSciences, 2(1), 30-36. 